\title{
GIS-based mapping of water-level fluctuations (WLF) and its impact on groundwater in an Agrarian District in Tamil Nadu, India
}

\section{P. J. Sajil Kumar ${ }^{1} \mathbb{D}$}

Received: 17 April 2020 / Accepted: 28 April 2021 / Published online: 16 June 2021

(C) The Author(s) 2021

\begin{abstract}
This study describes the results of groundwater table variation in Thanjavur District before and after the monsoon seasons. Groundwater-level data acquired by the field measurement and the elevation data have been obtained from the topographic survey. Groundwater is the major source for different sectors in this region, and the major portion was used for irrigation. The impacts of geology, soil types, topographic elevation, land-use changes were critically analyzed and identified that these factors are controlling the infiltration capacity. The maximum fluctuation in the water table was $2 \mathrm{~m}$ below the ground level; still, $50 \%$ of the study area is under threat of overexploitation. This is projecting to a severe shortage in water supply soon. Groundwater quality is threatening by the saline intrusion in the coastal region, and the irrigation return flows inland. The spatial variation maps were useful in visualizing the seasonal water level and fluctuation in Thanjavur. A proper monitoring system, efficient irrigation practices, and effective groundwater recharge structures are recommended.
\end{abstract}

Keywords Groundwater · Water-level fluctuation · GIS · Thanjavur

\section{Introduction}

Groundwater is a comprehensive source of water supply schemes all over the world, especially in rural areas (Nas \& Berkatay, 2010). Apart from the drinking water, it is one of the major sources for irrigation and ecosystem. Among several factors that control the quality of water, rainfall, quality of surface as well as recharged water, hydrogeochemical processes have a primary role in defining the groundwater quality (Vasanthavigar et al., 2010). During infiltration to the soil media, natural filtration occurs, and it is safe to drink without much treatment (Babiker et al., 2007). However, due to human interventions, this vital resource has been facing serious pressures in both quality and quantity point of view. This is calling for immediate attention from the scientists, water

P. J. Sajil Kumar

pjsajil@gmail.com; pj.sajil@fu-berlin.de

1 Hydrogeology Group, Institute of Geological Sciences, Freie Universität Berlin, Malteserstr. 74-100, 12249 Berlin, Germany 
resources managers, and policymakers to avoid further damage and put maximum possible efforts for its restoration.Query

Groundwater is one of the most widely used natural resources in India, which have been affecting the entire population. According to the World Bank report (2012), India is the highest user of groundwater in the world with an estimated use of $230 \mathrm{~km}^{2}$. The major sectors that use the groundwater are drinking, domestic, irrigation, and industries (Sajil Kumar et al., 2019). In all sectors, 90\% of the water is used for irrigation (Chindarkarand \& Grafton, 2019). Extensive and continuous usage of groundwater has resulted in the drying up of important aquifers in India (Sha, 2005). Many of the states in India are already classified under the critical or overexploited status. North Indian states are reported with highly depleted, and the more rising trend is observed in southern India. During the years 2002-2013, a drop in groundwater storage about $2 \mathrm{~cm} /$ year is found in northern India (Asoka et. al., 2017). In contrast, the groundwater storage has been increased by about 1-2 cm/year in south India. These changes are mainly attributed to the variation in precipitation. Measurement of periodic groundwater level is the primary step to understand the variation over time, hydrologic stresses on recharge, discharge, and storage, to develop groundwater models, and to suggest the management practices (Harun \& Kamaruddin, 2016). Usually, long-term data are necessary to systematically assess the hydrogeological condition of the aquifer.

Groundwater levels were monitored to understand the fluctuation and many along with other studies such as recharge estimation, groundwater quality studies, regional groundwater modeling, surface water interactions, rainfall-recharge relations (Panda et. al. 2007; Tedd et al. 2012; Chandra et al., 2015; Cai et. al., 2016; Deepesh Machiwal et al., 2019). The importance of groundwater-level monitoring has been appreciated, and several studies have performed in this direction. Groundwater levels can be measured from the selected wells in the monitoring network using conventional measurement tapes, electronic water-level indicators, airline pressure methods, acoustic methods, and automatic recording methods. Electronic water-level indicators are widely used methods, which have a dual conductor wire and a probe and an indicator. When the probe touches the water table, light or sound will signal, and the level is measured. In this study, the water level has been measured using an electronic sensor-based indicator.

Increased usage of geographical information systems in the water resources management is found to be very effective, especially in the spatial data interpretation and visualization. Tiwari et. al. (2016) successfully demonstrated the applicability of geostatistical mapping of the water-level fluctuations in Aosta Valley, Italy. Chadra et al.(2015) studied the hydrogeological factors and water table fluctuation in Dhanbad, India. Singh and Amrita (2017) presented the application of GIS in understanding the spatial and temporal changes in groundwater-level fluctuations in Haryana. Anand et al. (2020) identified the long-term and spatiotemporal changes in the groundwater levels based on GIS applications in the Lower Bhavani River basin, India.

This study is performed in Thanjavur District in Tamil Nadu, which is an agricultural dominated area near the east coast of India. The aim of this study is to understand the groundwater-level fluctuation and its spatial mapping using GIS-based geostatistical modeling approach. The influences on the groundwater-level variations are critically analyzed, and the impacts of the same on groundwater quality and quantity have been discussed in detail. This is a preliminary study of this kind in the study area and will be useful for groundwater management in the future. 


\section{Study area}

Thanjavur is a coastal district of Tamil Nadu, and it is a part of the Cauvery River basin and Vennar and Vettar sub-basins, marked by latitudes $10^{\circ} 48^{\prime} \mathrm{N}$ to $11^{\circ} 12^{\prime} \mathrm{N}$ and longitudes $78^{\circ} 48^{\prime}$ E to $79^{\circ} 38^{\prime}$ E (see Fig. 1). In this study area, the Pattukottai and Peravurani

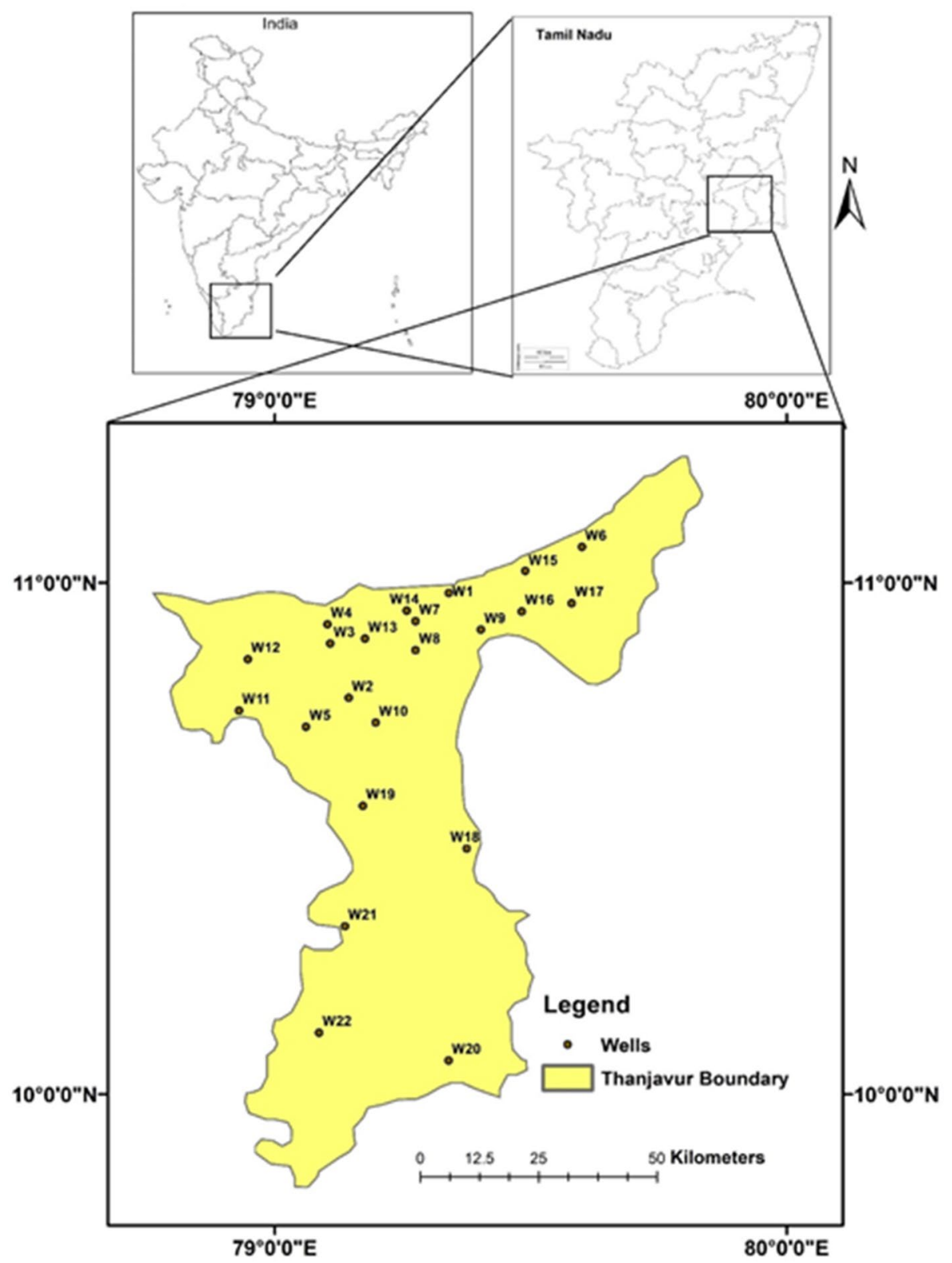

Fig. 1 Study area map showing the location of the wells 
blocks are sharing the boundary with the Bay of Bengal. Due to the intensive agricultural activity and enormous production of paddy, this district is known as the rice bowl of Tamil $\mathrm{Nadu}$; the climate of the area is tropical semi-arid climate with an average annual rainfall of $940 \mathrm{~mm}$, mainly two monsoon seasons- the SW and NE monsoons. SW monsoon spreads between June and September and the NE between October and January. Out of two seasons, the NE monsoon is the most dominant (Palanisami, 2008). The summer season is March to May; the maximum temperature goes up to $36^{\circ} \mathrm{C}$. As a coastal area, the humidity is high and usually varies between 70 and $85 \%$ (CGWB, 2009).

Geomorphology of the study area is marked by flood plain, delta plains, natural levees, and high sedimentary ground. Geology comprises mainly of deposition of Alluvial, Cretaceous, and Tertiary deposits. Alluvial and tertiary deposits are dominated among others (see Fig. 2; Palanisami, 2008). The Vallam region has a thick deposit of lateritic cap with impure limestone and sandstone of clay calcareous, silt, and argillaceous varieties. Coastal regions have mostly the famous Cuddalore sandstone deposits.

The geology of the area has Archaean, Cretaceous, Tertiary, and Quaternary formations. Archaean's formation is occupying comparatively less surface area, mainly found in Sengipatti village. Common rocks are gneisses, schists, granites, charnockites, and patches of

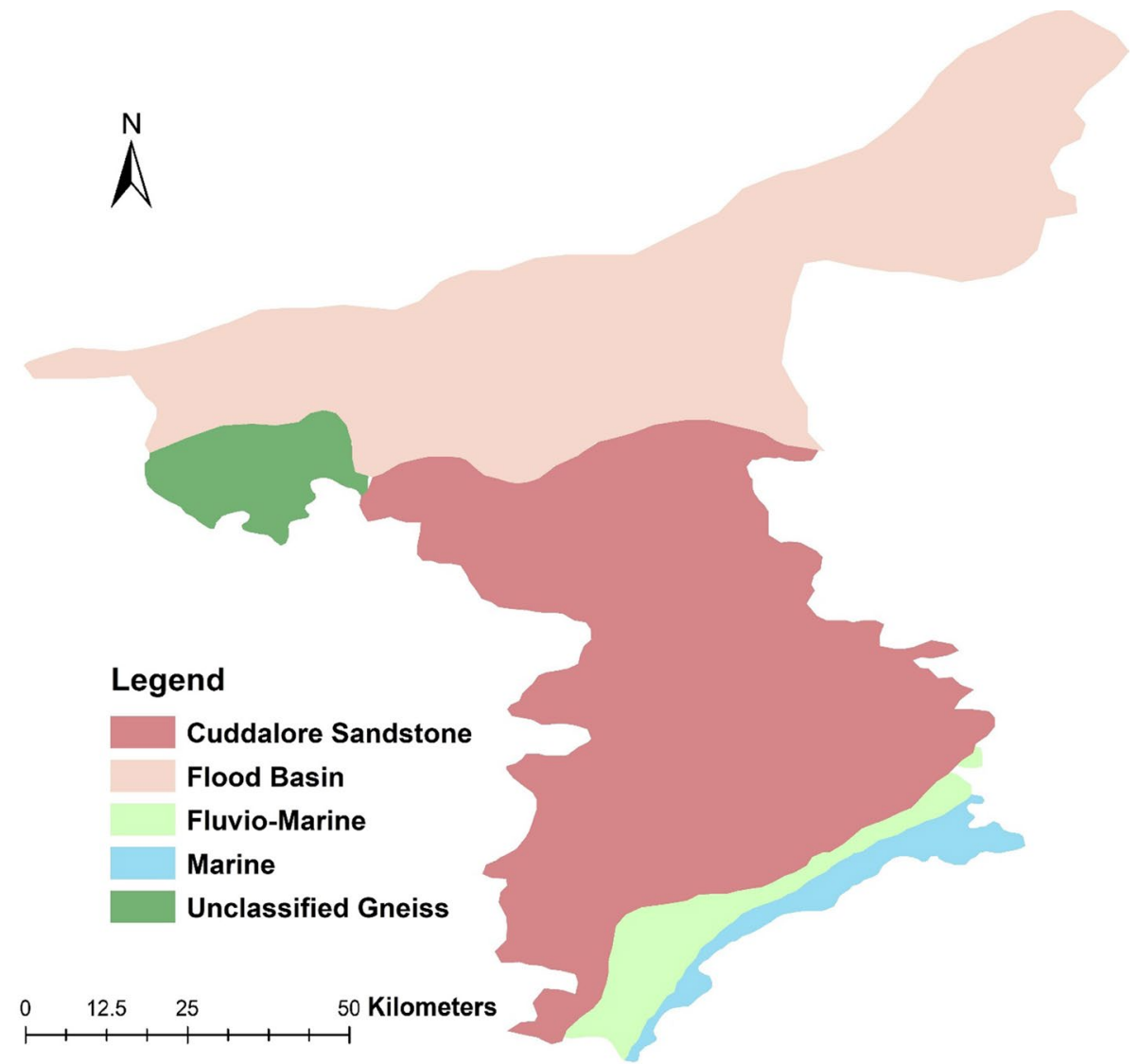

Fig. 2 Geology of the study area 
pegmatite veins in some locations. Overfilled by the Archaeans, the Cretaceous formations are seen as reddish calcareous sandstone. Tertiary formations are integrated beds of silts, clays, shales, sandy clays, and occasionally limestones, depths varying between 130 in the western region and $450 \mathrm{~m}$ in the central part. Quarternary formations are mainly generated by the Cauvery and Vennar basin. These sediments are fluvial and marine in origin. The thickness is varied from $12 \mathrm{~m}$ in the west and up to $40 \mathrm{~m}$ on the coast.

Hydrogeology of the study area shows that there are six different types of aquifers, namely Archaean aquifers, Cretaceous aquifers, Eocene aquifers, Miocene aquifers, Pliocene aquifers, and Quaternary aquifers. Archaean aquifers are found in the Sengipatti region, and the groundwater is contained in the weathered fractured rocks up to $12 \mathrm{~m}$ depth, in an unconfined to confined state. Cretaceous aquifers are coarse gravels, clays in the sand with maximum thickness of $50 \mathrm{~m}$. Groundwater is mostly under confined conditions. Water extraction method is generally dug wells of 8-10 m and bore wells of 25-30 m. Groundwater in the Eocene aquifers is under confined conditions, which has up to $80 \mathrm{~m}$ thickness comprised of sand, silt, and clay. Water extraction is mostly done by tube wells with 120-300 m. Miocene aquifers comprise mainly of Sand, stone, gravel with clay, and limestone. Water abstraction structure is tube wells of $150 \mathrm{~m}$ deep. Pleistocene aquifer is rarely found, and the major difference from Miocene aquifers is that has more diversified clay content. In the Quaternary aquifer, the proportion of sand-silt-clay is varying drastically; thus, the yield of the wells is considerably diverse. The thickness is between 3 and $25 \mathrm{~m}$.

\section{Materials and methods}

The overall methodology for this research work is prepared in the form a flow chart (see Fig. 3). A total of 22 wells were surveyed and selected for current and future studies. The wells usually dry in the summer season have been excluded from our study. Efforts are taken to choose wells to get the maximum spatial representation of the areas. A handheld GPS (GARMIN GPSMAP® 86i) was used to mark the latitude and longitude of the study area. Water levels were measured by the electronic portable water-level meter (Solinst 101). Measurement has been taken in pre-monsoon (July 2016) and post-monsoon season (January 2017). From these seasonal data, the water-level fluctuations were calculated using Microsoft Excel version 2016.

The seasonal water level and fluctuation were mapped using the geostatistical toolbox in ArcGIS 10.1. A geostatistical analysis is a form of the stochastic model, which helps accurately predict random values in the desired locations (Uyan \& Cay, 2013). Spatial correlation is the base of geostatistical models, which is generally expressed by variograms (Wameling, 2003). An empirical semivariogram is an essential tool in the geostatistical method, and this can be expressed as follows:

$$
\gamma(h)=\frac{1}{2 N(h)} \sum_{i=1}^{N(h)}\left[Z\left(x_{i}\right)-Z\left(x_{i}+h\right)\right]^{2}
$$

In this equation, $\gamma(h)$ indicates the semivariogram value at a distance, $h ; N(h)$ is the total number of the variable pairs separated this distance; and $\mathrm{Z}(\mathrm{x})$ is the value of the variable. There are different semivariograms such as spherical, exponential, Gaussian, and pure nugget effect commonly used in the analysis.

Kriging is one of the widely used and effective interpolation techniques (Borges et al., 2016; Wu et al., 2019). It is working on the principle assumption that the location near 
Fig. 3 Detailed methodology adopted for this research work

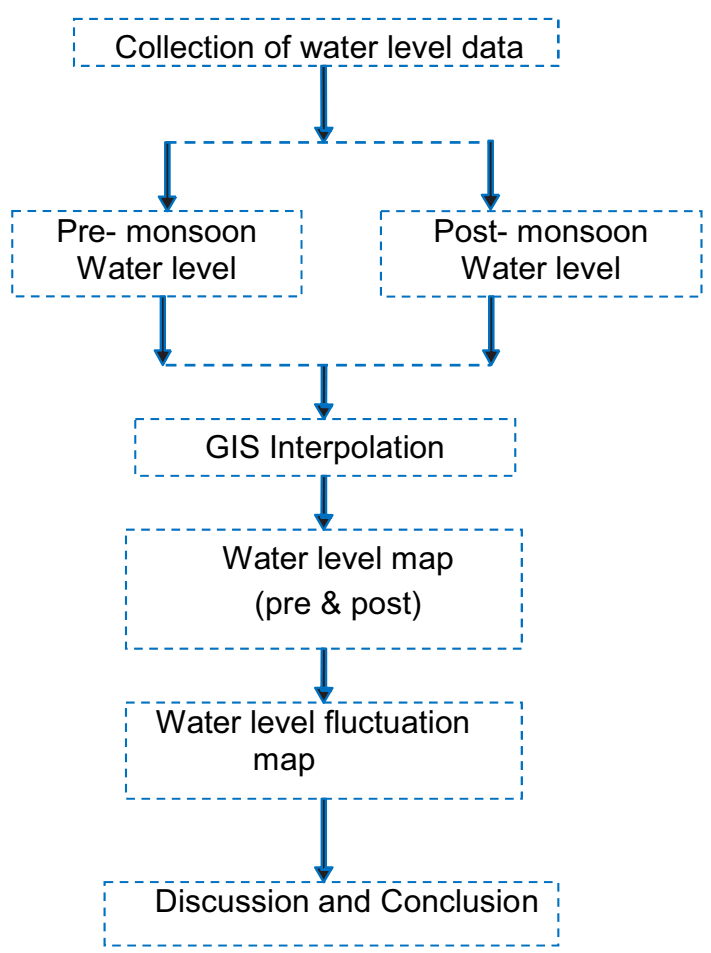

to the known point will have similar comparable values than those located farther away (Kumar, 2007). Using an empirical semivariogram, the data have been verified, and the best fit is identified by the line that represents points in the empirical semivariogram cloud graph, which appraises the spatial autocorrelation (Arslan, 2012). Then, spatial autocorrelation between predicted and measured locations, and the Kriging weights that are assigned to different measured parameters are obtained.

\section{Result and discussion}

The complete information about the location, elevation, seasonal water levels, and water table fluctuation with a statistical summary is shown in Table 1.

\section{The water level in Pre- and Post-monsoon}

Groundwater levels were measured from 22 wells in the study are for the pre- and postmonsoon seasons. Data show that the water level in pre-monsoon season varied from 1.31 to $13.37 \mathrm{~m}$ below ground level ( $\mathrm{mbgl}$ ); the average value was $5.23 \mathrm{mbgl}$. The majority of the water level was between 3.7 and $8.5 \mathrm{mbgl}$. The northern region of the study area has a very shallow water level. On the other hand, post-monsoon season has a relatively higher water table, as the depth was 1.07 to $13.0 \mathrm{mbgl}$., with an average of $4.65 \mathrm{mbgl}$. Most of the wells have a water level between 2 and $7 \mathrm{mbgl}$. In both seasons, the deepest water level is 


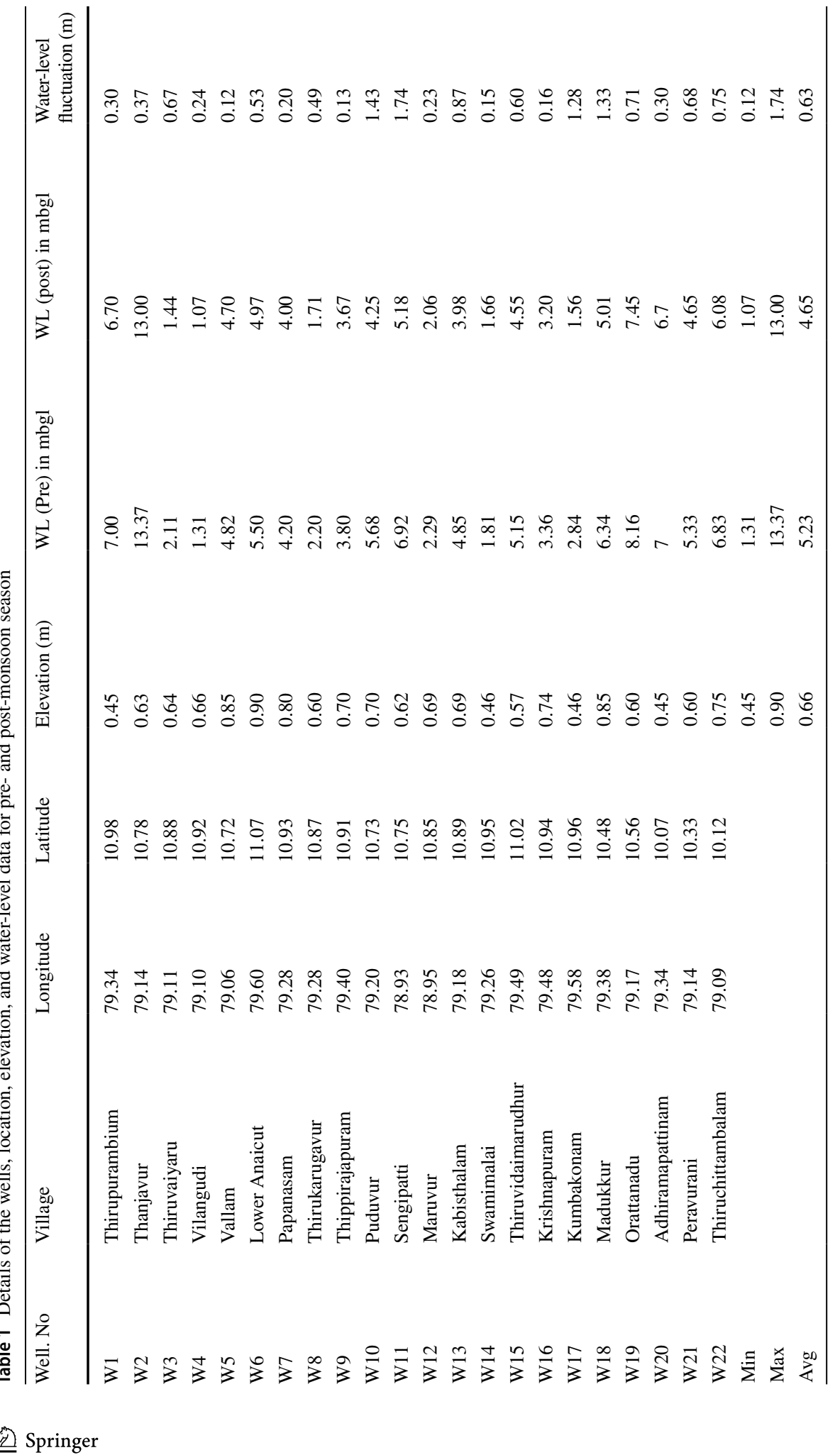


recorded in the Thanjavur Village. Figures 4 and 5 represent the groundwater level in the study area during pre- and post-monsoon season.

\section{Water-level fluctuation}

Figure 6 shows the water table fluctuation map of Thanjavur. The fluctuation was between 0.12 and $1.74 \mathrm{mbgl}$, with an average value of $0.63 \mathrm{mbgl}$. The fluctuation was over $1 \mathrm{~m}$ in wells W17, W18, W10, and W11, in which the well at Sengipatti (W11) has the highest deviation $1.74 \mathrm{~m}$. these wells are placed in the flood basin as well as the central Cretaceous formations. These regions have dense drainages by the Cauvery and other its tributaries. The higher hydraulic conductivity and highly fertile soils increased the water extraction for agricultural purposes. Additionally, the surface water-groundwater interactions make the area highly dynamic. Extreme hot climate in

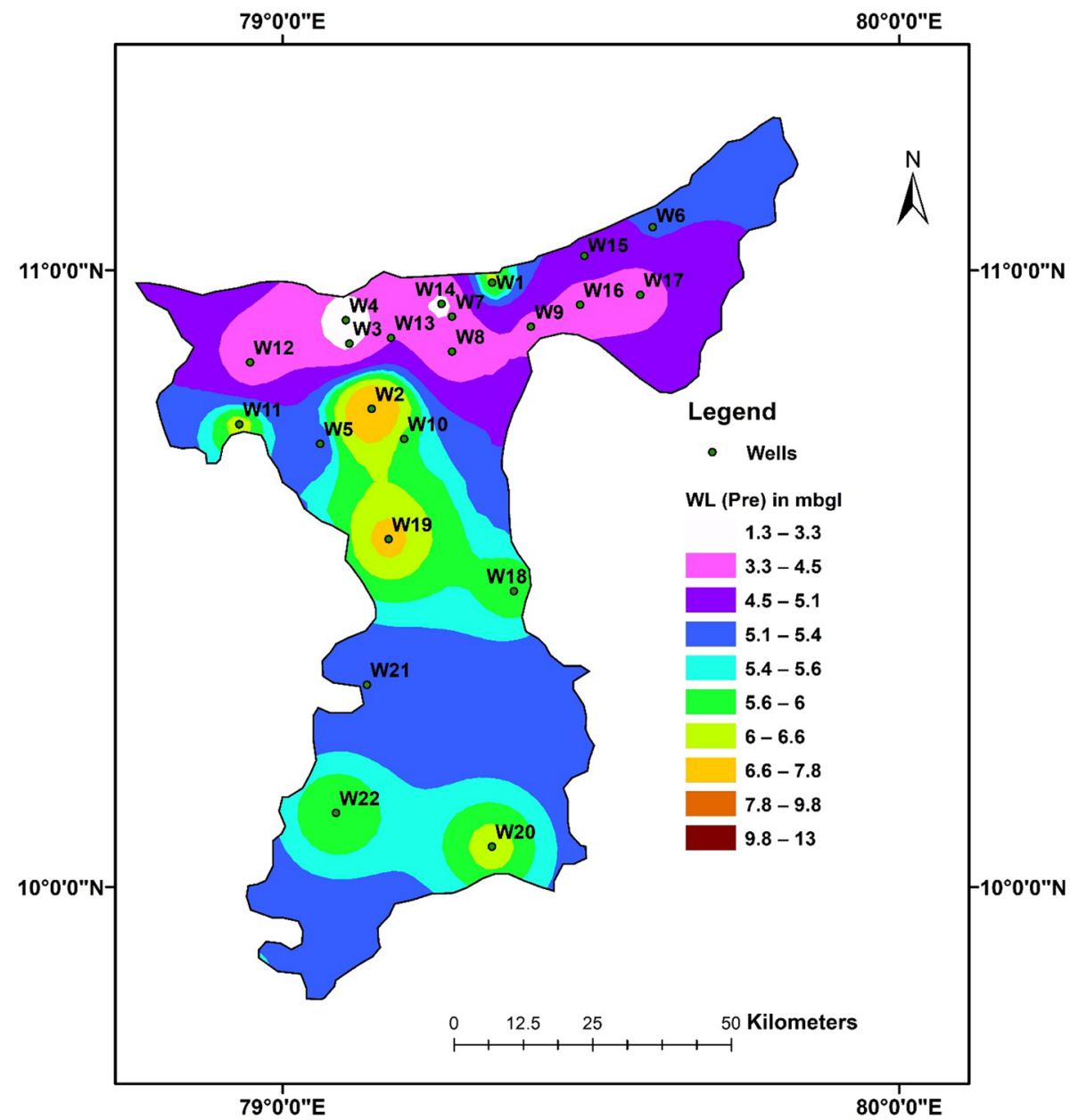

Fig. 4 Spatial variation in water level during pre-monsoon season in Thanjavur district 


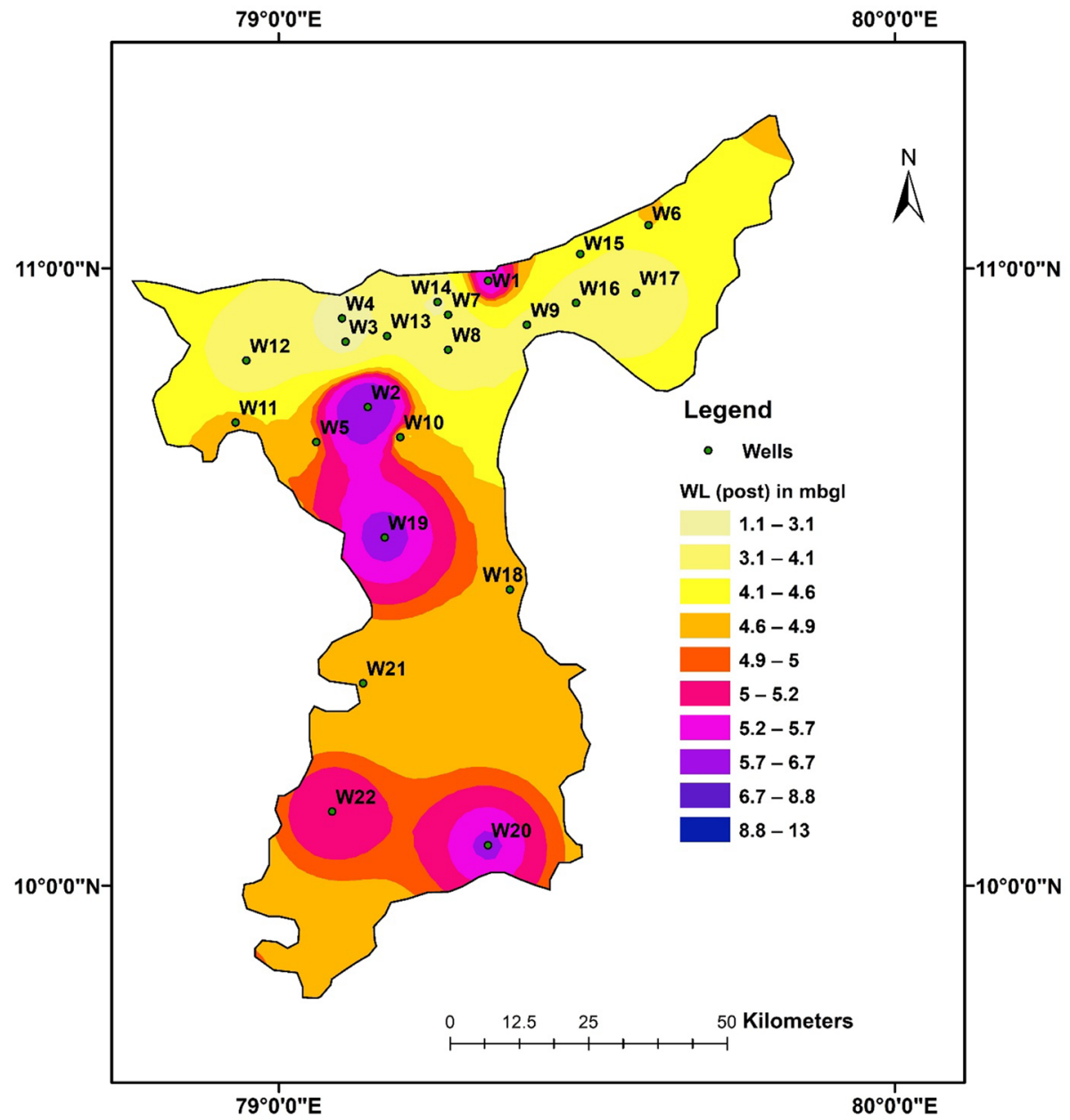

Fig. 5 Spatial variation in water level during post-monsoon season in Thanjavur district

the summer season and subsequent increase in the evaporation rate are also acting on the groundwater level.

\section{Factors influencing the water level}

There are several factors involved in the changes in the water table. The variation may be naturally over a certain period due to differences in weather sequences and precipitation patterns, streamflow, and geologic changes. Artificial factors may be mining activities, excess pumping out for different purposes, deforestation, and impervious surfaces on the landscape. 


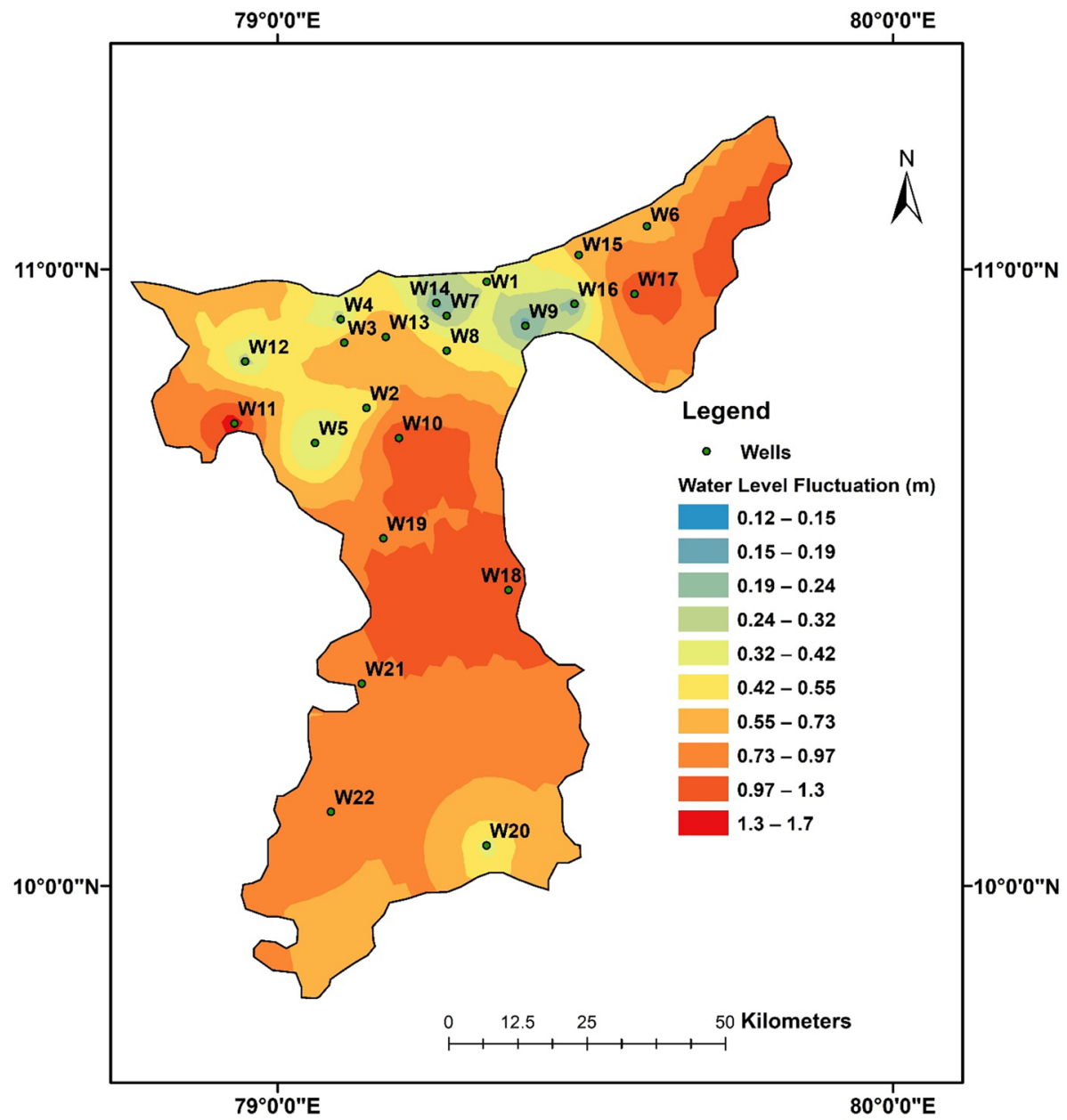

Fig. 6 Map showing the groundwater-level fluctuation in Thanjavur district

\subsection{Geology}

The water levels were measured from different geological formations, Fluvio-marine (W20), Cuddalore sandstone (W18, 19, 21 \& 22), Unclassified gneisses (W11), and Flood plains (all remaining wells). Different geological formations have variable aquifer parameters and water storage capacity. CGWB (2009) reported that the transmissivity of the main flowing deposits is renaming up to $1350 \mathrm{~m}^{2} /$ day, while the Cretaceous (Cuddalore sandstone) formations have the lowest $50 \mathrm{~m}^{2} /$ day. In general, the sandstones are compacted with clay content, which is not favorable for rainfall infiltration as those of marine deposits. Similar observations were observed by Tiwari et al. 2016, from the West Bokaro Coalfield in India. 


\subsection{Elevation}

The elevation of the land surface has been measured by a topographical survey with respect to mean sea level. The elevation data show that the topographical heights varied from 0.45 to $0.90 \mathrm{~m}$ with an average of $0.66 \mathrm{~m}$ (above MSL), indicating mostly plain terrain. Some of the earlier studies reported that there is a positive relation between elevation and water level (Chandra et al., 2015; Tiwari et al., 2016). Being a coastal region in the south and flooding planes in the north, this study region has plain topography. Thus, there is not much correlation observed for the same. Thus, groundwater flow is not controlled by the topographic height.

\subsection{Soil class}

Soil is the upper layer of earth curst that usually consists of organic matter, minerals, gases, liquids where plants are growing (Kumar et al., 2018). Soil texture, hydraulic conductivity, bulk density, porosity, etc. determine the infiltration capacity (Kumar et al., 2017; Owuor. et. al., 2016). It has control of the percentage of rainfall infiltration; additionally, it can decide the transmission rate and nature of the stream network (Owuor. et. al., 2016; Prince et. al., 2010). Because of different geological settings, the derived soils from different formations have mainly like sand, silt and clay superimposed sand, natural levee complexes in the Quaternary (Palanisamy 2008). Clays heavily weathered superimposed old drainage morphology in Pliocene, while Miocene has more Sands, clay bound, clays gravels (Velde $\&$ Druc, 1999). Cretaceous soils are reddish to yellowish calcareous sandstones, clays, and limestones. Comparing the water-level fluctuations with soils shows the lowest fluctuation $(0.12-0.39 \mathrm{mbgl})$ is marked in the northern part of the study area. The major reason for this is the very deep well-drained stratified loamy soils. We must consider that because of the comparatively high infiltration capacity, the water extracted for different purposes is recharged by the rainfall. On the other hand, the central regions have higher fluctuation ( 0.66 to $1.47 \mathrm{mbgl}$ ) compared to the northern region. This is because of the higher clay content in the soil resulting in less percolation, and the soil acts as impervious to generate excessive runoff (CGWB, 2009).

\subsection{Land use}

The land-use map of the study area has been derived from the Bhuvan thematic maps initiated by NRSA: ISRO. Resources-2 terrain corrected data from LISSIII sensor for three seasons were done for three cycles. In the latest version of LULC, data (3rd cycle) have been released in 2015. In this map, the GIS LULC vector layer of the first cycle was overlaid with the third cycle and the changes were corrected based on Resources at 2 LISS III imagery of 2015-2016 period. These thematic maps were of a 1:150,000 scale and found to be $90.7 \%$ accurate (NRRSA 2007). The land-use map of Thanjavur in Fig. 7 shows that most of the land area, i.e., 2690 out of $3390 \mathrm{~km}^{2}$, has been used for agricultural or related purposes; paddy is the dominated among crops, and around $70 \%$ of the people engaged in farming activities. The irrigation is mainly done by canals (80.23), tanks (0.26), tube wells (19.25), dug wells (0.26) (CGWB, 2009).

CGWB (2009) is reported that the net groundwater availability is $73605.60 \mathrm{Ha}$. $\mathrm{m}$. Out of this, a major share 48,608.27 Ha.m has been provided for the irrigation. The 
Fig. 7 Land-use map of Thanjavur district

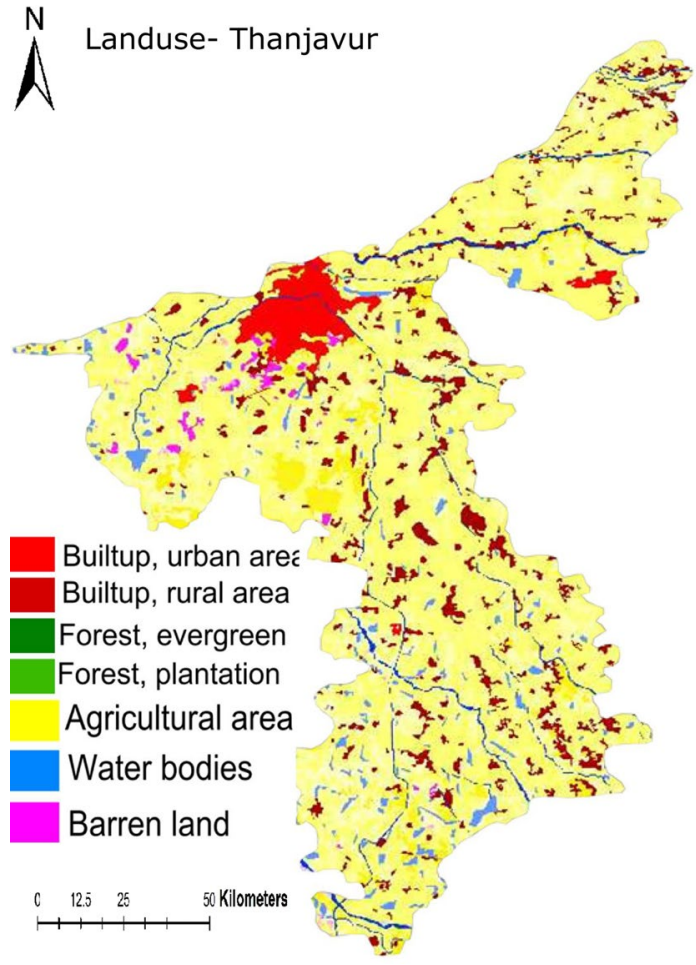

current draft for 4179.82 Ha.m has been used for domestic and industrial purposes. Thus, the total draft by all these sectors is 52788.09 Ha.m. It is to be noted that $70 \%$ of the groundwater has been pumped out every year irrespective of the climatic or any other environmental factors. There is an equilibrium between the recharge and discharge in any aquifers, which may be collapsed if there is a failure in the monsoon (Asoka et al.2017). Kumbakonam, Thiruppanandal, and Thiruvidaimarudur block out of 14 in the district has already been categorized as overexploited, and the other four blocks are either critical or semi-critical (CGWB, 2009). Apart from the intense agriculture, human settlements in these regions are high, and this is adding additional pressure to the groundwater. The pumping water for irrigation may have positive or negative impacts depending on the source of water (Leng et al., 2013). For example, irrigation with surface water pumped out of rivers, tanks, and reservoirs to the field may augment the groundwater level. On the other hand, pumping wells decreased the groundwater level.

\section{Impact of water-level changes on groundwater}

Water-level fluctuations had impacts on the chemical constituents in the groundwater as well as the overall groundwater reserve of the area (Rajmohan \& Elango, 2006; Sajil Kumar, 2016). The groundwater fluctuation can be an increase or decrease in the existing water table due to various natural and anthropogenic processes. However, the most common trend is the lowering of water tables worldwide (Fan et.al. 2013). Excess pumping from the existing 
reserve causes groundwater depletion, which is already evident from the Thanjavur area as $3 / 14$ blocked has been demarcated as overexploited. This may lead to additional expenses to the user to deepen the wells. Further, the groundwater is often connected to the lakes and rivers, maintaining the streamflow in dry seasons via seepage. This may ultimately lead to the loss of riparian vegetation (Zipper et al., 2019). In certain regions, the groundwater-level lowering can cause land subsidence. Similar results were reported from China (Shi et al., 2012) and Taiwan (Chen et. al., 2010).

Different factors that are leading to the fluctuation of groundwater have been already discussed in the earlier sections. The connection between the groundwater and the surface water is well known and impacting each other. Groundwater-level fluctuation indicates the flow of water from groundwater to surface water resources like rivers and lakes (Sophocleous, 2002). Often, the surface water levels instantly fluctuate with the response to the precipitations, surface runoff, and climatic conditions (Winter, 1995). Generally, the groundwater contamination is occurring in the agricultural fields due to the fertilizers and irrigation return flows, which results in the solute transfer to the surface waters. In a study in Noord-Brabant, Netherlands reported that around $47 \%$ of total-N loads, $47 \%$ of total-P, $69 \%$ of $\mathrm{Zn}, 16 \%$ of $\mathrm{Cu}$, and $74 \%$ of $\mathrm{Ni}$ in the surface waters could be attributed to the agricultural lands (Van Vliet et al., 2006). Similarly, in the industrial regions, the untreated effluents may contaminate the surface water. When the groundwater table is low, surface water can flow to the groundwater and can cause contamination in groundwater.

The major impact on water-level lowering on groundwater quality and potable water supply is the seawater intrusion in the coastal region (Mahlknech et al., 2017; Sajil Kumar et.al., 2014). The high dense seawater is generally underlined by less dense freshwater in equilibrium, and this will destroy the ratio, resulting in the encroachment of seawater to aquifers (van Camp et al.2014). The southern and southwestern boundary of the Thanjavur District is bounded by the Bay of Bengal, and overexploitation results in groundwater Salinization (Sajil Kumar et. al., 2019). As the highest water consumption section, pumping for irrigation has a considerable impact on the groundwater quality and quantity. A similar remark has been reported by Rotiroti et al.. (2019) from northern Italy. There are studies reporting the groundwater quality changes due to fluctuation in groundwater (Rajmohan \& Elango, 2006; Sajil Kumar, 2016). The quality changes may attribute to various hydrogeochemical processes such as dissolution, dilution, rock-water interactions, evaporation, rock weathering, etc., and the improvement or the deterioration in the water quality will primarily depending on the lithology, $\mathrm{pH}$, temperature, and redox conditions within the aquifer. In contrast, the groundwaterlevel increase due to excess irrigation causes waterlogging and subsequent increase in salinity (Park et al. 2018). Shallow or very near water table increases the evaporation process, which results in concentrating the salts in the root zone and finally seeped to groundwater. This may convert the $\mathrm{Ca}-\mathrm{HCO}_{3}$ type of water to $\mathrm{Na}-\mathrm{Cl}$ type (Foster et. al. 2018). The usage of pesticides, manures, and fertilizers may furthermore increase the risk of heavy metals, nitrate, potash, and phosphate contamination (Zhang et al., 2016). Thanjavur is dominated by agricultural practices, and excess irrigation is very common here, thus posing a serious health concern via this pathway. 


\section{Conclusions}

Groundwater-level fluctuations during pre- and post-monsoon in the Thanjavur District are studied using hydrogeological and GIS mapping methods. The water table fluctuation was ranged from 0.12 to $1.74 \mathrm{mbgl}$. The spatial map of water table fluctuation was a convenient tool for demarcating the potential zones. The highest is recorded from the Sengipatti Village, and a moderate level of fluctuation was observed at the central and northeast regions of the district. It is found that 2690 out of $3390 \mathrm{~km}^{2}$ of the area has been used for agricultural and used the $80 \%$ of the groundwater resources. Out of fourteen, three blocks were found to be overexploited, and four are either critical or semi-critical condition. The major factors controlling the water level are geology, soil, elevation, and land-use pattern. Groundwater quality is facing serious threats due to excess pumping and subsequent seawater intrusion in the coastal region in the south. In the agricultural areas, the irrigation return flow is acting as the non-point source pollution with salinity, nitrate, phosphate, and heavy metal contaminations. This study recommends quarterly monitoring of both quantitative and qualitative monitoring to adequate groundwater management.

Funding Open Access funding enabled and organized by Projekt DEAL.

Open Access This article is licensed under a Creative Commons Attribution 4.0 International License, which permits use, sharing, adaptation, distribution and reproduction in any medium or format, as long as you give appropriate credit to the original author(s) and the source, provide a link to the Creative Commons licence, and indicate if changes were made. The images or other third party material in this article are included in the article's Creative Commons licence, unless indicated otherwise in a credit line to the material. If material is not included in the article's Creative Commons licence and your intended use is not permitted by statutory regulation or exceeds the permitted use, you will need to obtain permission directly from the copyright holder. To view a copy of this licence, visit http://creativecommons.org/licenses/by/4.0/.

\section{References}

Anand B, Karunanidhi D, Subramani T, Srinivasamoorthy K, Suresh M (2020) Long-term trend detection and spatiotemporal analysis of groundwater levels using GIS techniques in Lower Bhavani River basin, Tamil Nadu, India. Environment, Development and Sustainability volume 22, pages $2779-2800$

Arslan, H. (2012). Spatial and temporal mapping of groundwater salinity using ordinary kriging and indicator kriging: The case of Bafra Plain, Turkey. Agricultural Water Management, 113, 57-63

Tiwari, A. K., Singh, P. K., Chandra, S., \& Ghosh, A. (2016). Assessment of groundwater level fluctuation by using remote sensing and GIS in West Bokaro coalfield. Jharkhand, India, ISH Journal of Hydraulic Engineering, 22(1), 59-67. https://doi.org/10.1080/09715010.2015.1067575

Asoka, A., Gleeson, T., Wada, Y., \& Mishra, V. (2017). Relative contribution of monsoon precipitation and pumping to changes in groundwater storage in India. Nature Geoscience, 10, 09-117

Babiker, I. S., Mohamed, M. A. A., \& Hiyama, T. (2007). Assessing groundwater quality using GIS Water Resour. Manage, 21, 699-715. https://doi.org/10.1007/s11269-006-9059-6

Borges, Pd. A., Franke, J., da Anunciação, Y. M. T., Weiss, H., \& Bernhofer, C. (2016). Comparison of spatial interpolation methods for the estimation of precipitation distribution in Distrito Federal. Brazil Theoretical and Applied Climatology, 123(1), 335-348. https://doi.org/10.1007/s00704-014-1359-9

Cai, Z., \& Ofterdinger, U. (2016). Analysis of groundwater-level response to rainfall and estimation of annual recharge in fractured hard rock aquifers. NW Ireland Journal of Hydrology, 535, 71-84

CGWB (2009) Groundwater profile Thanjavur district. Technical report series 
Chandra, S., Singh, P. K., Tiwari, A. K., Panigrahy, B., \& Kumar, A. (2015). Evaluation of hydrogeological factor and their relationship with seasonal water table fluctuation in Dhanbad district, Jharkhand. India ISH Journal of Hydraulic Engineering, 21, 193-206

Chen, C., Wang, C., Hsu, Y., Yu, S., \& Kuo, L. (2010). Correlation between groundwater level and altitude variations in land subsidence area of the Choshuichi Alluvial Fan. Taiwan Engineering Geology, 115, 122-131

Chindarkar, N., \& Grafton, R. Q. (2019). India's depleting groundwater: When science meets policy. Asia and Pacific Policy Studies, 6, 108-124. https://doi.org/10.1002/app5.269

Deepesh Machiwal, P. C., Moharana, S. K., Srivastava, V., \& Bhandari, S. L. (2019). Exploring temporal dynamics of spatially-distributed groundwater levels by integrating time series modeling with geographic information system. Geocarto International. https://doi.org/10.1080/10106049.2019.1648561

Fan, Y., Li, H., \& Miguez Macho, G. (2013). Global patterns of groundwater table depth. Science, 339, 940-943. https://doi.org/10.1126/science.1229881,2013

Foster, S., Pulido-Bosch, A., Vallejos, Á., Molina, L., Llop, A., \& MacDonald, A. M. (2018). Impact of irrigated agriculture on groundwater-recharge salinity: a major sustainability concern in semi-arid regions. Hydrogeology Journal. https://doi.org/10.1007/s10040-018-1830-2

Harun N, Kamaruddin AHC (2016) Groundwater Level Monitoring using Levelogger and the Importance of Long-Term Groundwater Level Data. MALAYSIAN NUCLEAR AGENCY R\&D SEMINAR 2016At: Malaysian Nuclear agency

Kumar, V. (2007). Optimal contour mapping of groundwater levels using universal kriging-a case study. Hydrological Sciences Journal, 52, 1038-1050. https://doi.org/10.1623/hysj.52.5.1038

Kumar, A., Mishra, S., Kumar, A., \& Singhal, S. (2017). Environmental quantification of soil elements in the catchment of hydroelectric reservoirs in India. Human and Ecological Risk Assessment: an International Journal, 23(5), 1202-1218. https://doi.org/10.1080/10807039.2017.1309266

Kumar, A., Sharma, M. P., \& Yang, T. (2018). Estimation of carbon stock for greenhouse gas emissions from hydropower reservoirs. Stoch Environ Res Risk Assess, 32, 3183-3193

Leng, G., Huang, M., Tang, Q., Gao, H., \& Leung, L. R. (2013). Modeling the effects of groundwaterfed irrigation on terrestrial hydrology over the conterminous United States. Journal of Hydrometeorology, 15(3), 957-972. https://doi.org/10.1175/JHM-D-13-049.1

Mahlknecht, J., Merchán, D., Rosner, M., Meixner, A., \& Ledesma-Ruiz, R. (2017). Assessing seawater intrusion in an arid coastal aquifer under high anthropogenic influence using major constituents, $\mathrm{Sr}$ and B isotopes in groundwater. Science of the Total Environment, 587, 282-295

Nas, B., \& Berktay, A. (2010). Groundwater quality mapping in urban groundwater using GIS. Environmental Monitoring and Assessment, 160, 215-227. https://doi.org/10.1007/s10661-008-0689

NRRSA (2007) National landuse and land cover mapping using multi-temporal AwiFS data. https://bhuvan-app1.nrsc.gov.in/2dresources/thematic/LULC250/0506.pdf

Owuor, S. O., Butterbach-Bahl, K., Guzha, A. C., Rufino, M. C., Pelster, D. E., Díaz-Pinés, E., \& Breuer, L. (2016). Groundwater recharge rates and surface runoff response to land use and land cover changes in semi-arid environments. Ecological Processes. https://doi.org/10.1186/ s13717-016-0060-6

Palanisami K (2008) National Agricultural Development Programme (Nadp), District Agriculture Plan Thanjavur District, Coimbatore - 641003: Centre for Agricultural and Rural Development Studies, Tamil Nadu Agricultural University.

Panda, D. K., Mishra, A., Jena, S. K., James, B. K., \& Kumar, A. (2007). The influence of drought and anthropogenic effects on groundwater levels in Orissa, India. Journal of Hydrology, 343, 140-153

Park, Y., Kim, Y., Park, S. K., Shin, W. J., \& Lee, K. S. (2018). Water quality impacts of irrigation return flow on stream and groundwater in an intensive agricultural watershed. Science of the Total Environment, 630, 859-868

Price, K., Jackson, C. R., \& Parker, A. J. (2010). Variation of surficial soil hydraulic properties across land uses in the southern Blue Ridge Mountains, North Carolina, USA. Journal of Hydrology, 383, 256-268

Singh, O., \& Amrita, K. (2017). GIS-based spatial and temporal investigation of groundwater level fluctuations under rice-wheat ecosystem over Haryana. Journal of the Geological Society of India, 89, 554-562

Vasanthavigar, M., Srinivasamoorthy, K., Vijayaragavan, K., Rajiv Ganthi, R., Chidambaram, S., Anandhan, P., \& Manivannan, R. (2010). Vasudevan S (2010) Application of water quality index for groundwater quality assessment: Thirumanimuttar sub-basin, Tamilnadu. India. Environ Monit Assess, 171, 595-609. https://doi.org/10.1007/s10661-009-1302-1

Velde, B., \& Druc, I. C. (1999). Clay minerals and their properties archaeological ceramic materials: Origin and utilization. (pp. 35-58). Springer. 
Rotiroti, M., Bonomi, T., Sacchi, E., McArthur, J. M., Stefania, G. A., Zanotti, C., et al. (2019). The effects of irrigation on groundwater quality and quantity in a human-modified hydro-system: The Oglio River basin, Po Plain, northern Italy. Science of the Total Environment, 672, 342-356. https:// doi.org/10.1016/j.scitotenv.2019.03.427

Rajmohan, N., \& Elango, L. (2006). Hydrogeochemistry and its relation to groundwater level fluctuation in the Palar and Cheyyar river basins, southern India. Hydrological Processes, 20(11), 2415-2427

Sajil Kumar, P. J., Elango, L., \& James, E. J. (2014). Assessment of hydrochemistry and groundwater quality in the coastal area of South Chennai, India. Arabian Journal of Geosciences , 7, 2641-2653. https:// doi.org/10.1007/s12517-013-0940-3

Sajil Kumar, P. J. (2016). Influence of water level fluctuation on groundwater solute content in a tropical south Indian region: A geochemical modelling approach. Model Earth System Environment, 2, 171. https://doi.org/10.1007/s40808-016-0235-2

Sajil Kumar PJ, Anju AM, Vicky SE (2019) Hydrogeochemical analysis of Groundwater in Thanjavur district, Tamil Nadu; Influences of Geological settings and land use pattern Geology, Ecology, and Landscapes https://doi.org/10.1080/24749508.2019.1695713

Shah, T. (2005). Groundwater and human development: Challenges and opportunities in livelihoods and environment. Water Science and Technology, 51(8), 27-37

Shi, X., Fang, R., Wu, J., Xu, H., Sun, Y., \& Yu, J. (2012). Sustainable development and utilization of groundwater resources considering land subsidence in Suzhou, China. Engineering Geology, 124, 77-89. https://doi.org/10.1016/j.enggeo.2011.10.005

Tedd, KM, Misstear, BDR, Coxon, C, DalyD, Williams NHH (2012) Hydrogeological insights from groundwater level hydrographs in SE Ireland.QJ Eng. Geol.Hydrogeol. 45 (1), 19-30

Singh, O., \& Amrita, K. (2017). GIS-based spatial and temporal investigation of groundwater level fluctuations under rice-wheat ecosystem over Haryana. Journal of the Geological Society of India, 89(5), 554-562. https://doi.org/10.1007/s12594-017-0644-5

Sophocleous, M. (2002). Interactions between groundwater and surface water: The state of the science. Hydrogeology Journal, 10, 52-67

Uyan, M., \& Cay, T. (2013). Spatial analyses of groundwater level differences using geostatistical modelling. Environmental and Ecological Statistics, 20, 633-646.

Van Camp, M., Mtoni, Y., Mjemah, I. C., Bakundukize, C., \& Walraevens, K. (2014). Investigating seawater intrusion due to groundwater pumping with schematic model simulations: the example of the Dar es Salaam coastal aquifer in Tanzania. Journal of African Earth Sciences, 96, 71-78. https://doi.org/10. 1016/j.jafrearsci.2014.02.012

Van Vliet, M.E., Passier, H.F., Van der Grift, B., Brils, J., Joziasse, J., Schipper, P., Clement, P., Van Lanen, R., 2006. Herkomst stoffen in het Maasstroomgebied, TNO-report 2006-U-R0095/B, TNO Built Environment and Geosciences, Utrecht, The Netherlands (in Dutch).

Wameling, A. (2003). Accuracy of geostatistical prediction of yearly precipitation in Lower Saxony. Environmetrics, 14, 699-709

Winter TC (1995) Recent advances in understanding the interaction of groundwater and surface water. Rev Geophys. (Suppl):985-994

World Bank (2012) India groundwater: A valuable but diminishing resource. http://www.worldbank.org/en/ news/feature/2012/03/06/india-groundwater-critical-diminishing (accessed 25 October 2017)

Wu, C.-Y., Mossa, J., Mao, L., \& Almulla, M. (2019). Comparison of different spatial interpolation methods for historical hydrographic data of the lowermost Mississippi River. Annals of GIS, 25(2), 133-151. https://doi.org/10.1080/19475683.2019.1588781

Zhang, X., Sun, M., Wang, N., Huo, Z., \& Huang, G. (2016). Risk assessment of shallow groundwater contamination under irrigation and fertilization conditions. Environment and Earth Science, 75, 603

Zipper, S. C., Gleeson, T., Kerr, B., Howard, J. K., Rohde, M. M., Carah, J., \& Zimmerman, J. (2019). Rapid and accurate estimates of streamflow depletion caused by groundwater pumping using analytical depletion functions. Water Resources Research, 55(7), 5807-5829. https://doi.org/10.1029/2018W R024403

Publisher's Note Springer Nature remains neutral with regard to jurisdictional claims in published maps and institutional affiliations. 